\title{
Effectiveness of Mukhaprakshalan by Varun qwath \& Jatiphaladi Lepa in Mukhadushika (Acne Vulgaris)
}

\author{
Research Article
}

\section{Prajkta Anil Hagone1*, Vaishali Kuchewar ${ }^{2}$}

1. P.G Scholar, 2. Dean and Professor, Department of Kayachikitsa

Mahatma Gandhi Ayurvedic College, Salod (H), Maharashtra, India.

\begin{abstract}
Due to increased competition of earning prosperity in today era human adopted not only lifestyle but also food habits of western culture which is chiefly responsible to derangement in their physiology and responsible to number of skin disorder like Yuvan pidika (acne vulgaris). In Ayurveda vitiation of Vata, Kapha and Rakta are etiological factor that give rise to Yuvan pidika. That is why there is a need of such treatment that contains Vata kapha shamaka and Raktasodhaka property. For this Varun quath Mukhaprakshal and Jatiphaladi lepa were selected for the study on 30 registered patients. Both drugs were applied twice a day for 15 days. This study shows highly significant result to ameliorate the symptom of Yuvan pidika especially on pidika. Both these drugs proved their efficacy to manage Yuvan pidika by making homeostasis of Vata, Kapha and Rakta.
\end{abstract}

Key Words: Yuvan pidika, Acne vulgaris, Varun quath, Jatiphaladi Lepa.

\section{Introduction}

Face is one among the most exposed part of the body which reflects the confidence, personality and self-esteem of a person. If such an important part of the body gets disturbed by any pathology, it is not only affects the physic of the person but also the psychology. Acne is one of them.

Acne vulgaris affects $\sim 85 \%$ of young adults aged between 12-25 years.(1) This disease causes a severe psychosocial burden in the patients, about $30 \%$ to $50 \%$ of teenagers experience psychological complications associated with acne. Acne amongst the top three most prevalent skin conditions in the general population. (2),(3),(4)

Acne is a common chronic inflammatory condition of skin with substantial cutaneous and psychological disease.(5) This disease is characterised by the formation of comedones [blackheads], erythematous papules, also in a few cases, nodules or cyst and scarring (6) It appears frequently on the cheeks but also involves forehead, chin, and nose, on back, chest and mid arms (7) It develops earlier in females than males personals. A highest incidence and harshness occurs between the age of 14-17 years in females and 16-19 years in males.(8)

In Ayurveda acne vulgaris is considered as Mukhadushika (Yuvvan pidika) due to similarities of symptoms. It is described under the Kshudraroga (9)

* Corresponding Author:

Prajkta Anil Hagone

PG scholar, Department of Kayachikitsa,

Mahatma Gandhi Ayurvedic College,

Salod $(\mathrm{H})$,

Maharashtra, India

Email Id: p6hagone@gmail.com
The name 'Mukhadushika' indicates involvement of face and 'Yuvanapidika' explains its onset in young age. (10)According to Ayurveda Mukhadushika caused due to the vitiated Kapha, Vata and Rakta characterized by the lesions resembling in shape that of Shalmali kantaka (thorn of Shalmali malabarica).(11) The clinical features of Mukhadushika are Pidaka (eruptions), Saruja (pain), Ghana (thickness of eruption), Medogarbha (comedones) (12) Kandu (itching), Saraktata (bleeding)(13) Daha (burning sensation), Snigdhata (greasy skin).

The treatment action of Mukhadushika is of two types shodhana chikitsa and shamana chikitsa (14) including Vamana, Nasya and Siravedha Lepa and Pralepa.

\section{Need of the study}

As Acne is a very common disease in adult. It leads to Psychological, social and economic impairment. It may affect self-esteem (15). In Ayurveda, various herbs are described as effective remedy for it. So this study is planned to revalidate the effect of Varun qwath \& Jatiphaladiyog in Mukhadushika (16).

\section{Aims and Objectives \\ Aim}

The aim of this study is to assess the effectiveness of Mukhaprakshalan by Varun qwath \& Jatiphaladi Lepa in Mukhadushika.

\section{Objectives}

- To study the predominance of Sharirik and Mansik Prakriti of the patients of Mukhadushika.

- To assess the predominant area of face in Mukhadushika.

- To study the effect of Varun qwath \& Jatiphaladi Lepa on Comedones, Papules, Pustules and nodulocystic lesion by Global acne scale. 
Prajkta Anil Hagone et.al., Effectiveness of Mukhaprakshalan by Varun qwath \& Jatiphaladi Lepa in Mukhadushika (acne

\section{Materials and Methods}

\section{Drug source}

The raw drugs required for Varun Qwath and Jatiphaladi Lepa were procured from authentified shop.

All drugs were authenticated by Department of Dravyaguna, and Qwath and Churna were prepared in Rasashala and its Analytical study was done for the authentification of drug

-Study design : Single arm

-Study type : Interventional study

-Sample size : 30

Inclusion criteria:

- Subjects of either sex with the age group between 16 to 35 years.

- Patients having more than 5 pidika on face

- Chronicity less than 5 year.

Exclusion criteria

- Patient on anti-tubercular drug therapy.

- Associated with other forms of skin diseases.

Withdrawal criteria

- If any untoward side effects or complications occur during the course of study.

- If patient is not ready to continue the treatment.

\section{Plan of study: -}

Total 30 patients accomplishing the inclusion criteria were taken; informed consent was taken from each patient.

\section{Treatment protocol}

Patient was adviced to wash the face two times a day with Varun Qwath before application of Jatiphaladi lepa. Then asked to apply Jatiphaladi lepa (Q.S for thin layer) over the affected area by mixing with plain water and ask to wash it after getting it near to dry. This treatment was given for 15 days

\section{Assessment of patient}

Patients were assessed on the basis of Global acne grading system on 0 th and 15 th day

Table No. 1. The global acne grading system (17)

\section{Location}

Forehead

Right cheek

Left cheek

Nose

Chin

Upper chest and back

Type of lesion

No Lesions

Comedones

Papules

Pustules

Nodules

Factor

2
2
2
1
1
3
Point
0
1
2
3
4

Gradation of acne severity

\begin{tabular}{|l|c|}
\hline Severity & Score \\
\hline Mild & $1-18$ \\
\hline Moderate & $19-30$ \\
\hline Severe & $31-38$ \\
\hline Very severe & 39 \\
\hline
\end{tabular}

That severity grade is calculated using the formula: Local score $=$ Factor $\times$ Grade $(0-4)$

\section{Observations and Results \\ Figure no. 1 Comparison of result before and after treatment}
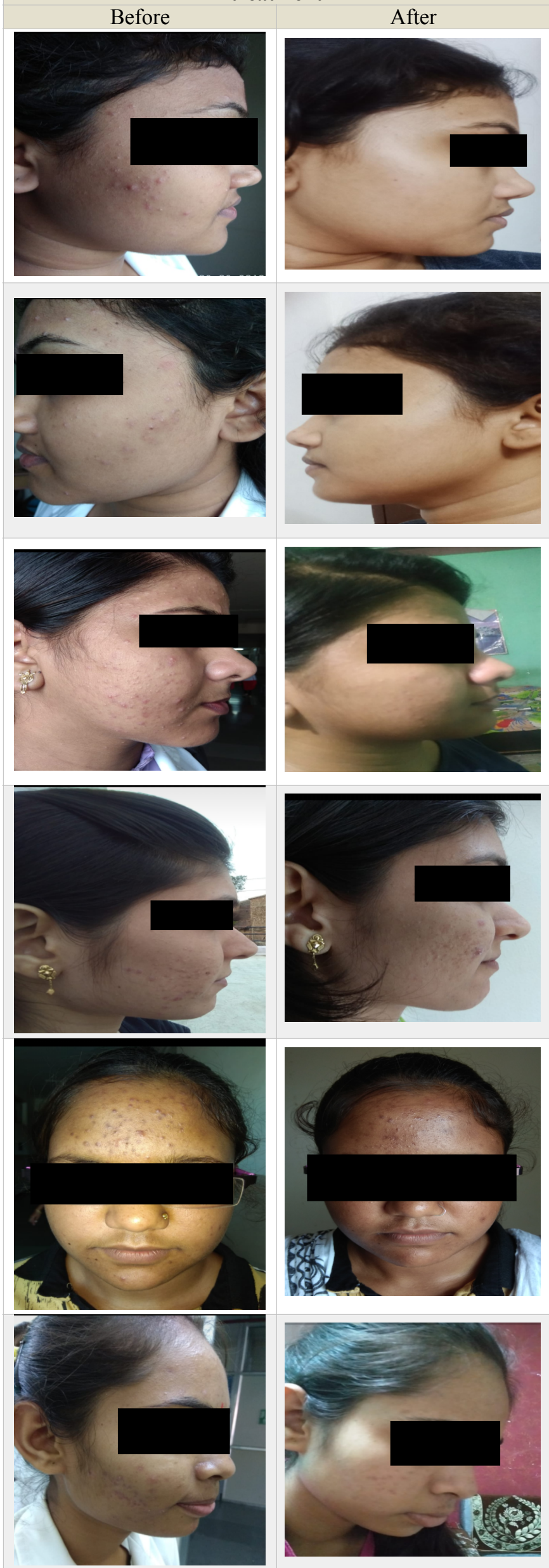
Digital photographs of the affected areas were taken before and after treatment.

Total 35 patients were recruited for the study. Out of that 30 patients had completed the treatment and 5 patients could not complete the treatment as they did not turn up for follow up.

Table No. 1: Age wise distribution of patients

\begin{tabular}{|l|c|c|}
$\begin{array}{c}\text { Age } \\
\text { Group(yrs) }\end{array}$ & No of patients & Percentage \\
\hline $\mathbf{1 6 - 2 0}$ yrs & 7 & $23.33 \%$ \\
\hline $\mathbf{2 1 - 2 5}$ yrs & 12 & $40 \%$ \\
\hline $\mathbf{2 6 - 3 0}$ yrs & 8 & $26.67 \%$ \\
\hline $\mathbf{3 1 - 3 5}$ yrs & 3 & $10 \%$ \\
\hline Total & 30 & $100 \%$ \\
\hline Mean \pm SD & $23.93 \pm 4.56(17-35 \mathrm{yrs})$ \\
\hline
\end{tabular}

Table No. 2: Gender wise distribution of patients

\begin{tabular}{|l|c|c|}
\hline \multicolumn{1}{|c|}{ Gender } & No of patients & Percentage \\
\hline Female & 23 & $76.67 \%$ \\
\hline Male & 7 & $23.33 \%$ \\
\hline Total & 30 & $100 \%$ \\
\hline
\end{tabular}

Table No. 3 : Distribution of patients according to area involvement

\begin{tabular}{|l|c|c|}
\hline Area involvement & $\begin{array}{c}\text { No of } \\
\text { patients }\end{array}$ & Percentage \\
\hline
\end{tabular}

\begin{tabular}{|l|c|c|}
\hline Cheeks & 11 & 36.67 \\
\hline Forehead + Cheeks & 5 & 16.67 \\
\hline Forehead & 3 & 10.00 \\
\hline Cheeks + Nose & 3 & 10.00 \\
\hline Forehead + Cheeks + Nose & 3 & 10.00 \\
\hline Cheeks + Chin & 2 & 6.67 \\
\hline Forehead + Nose & 2 & 6.67 \\
\hline Cheeks + Nose + Chin & 1 & 3.33 \\
\hline
\end{tabular}

Table No. 4: Distribution of patients according to duration of Mukhadushika (in years)

\begin{tabular}{|c|c|c|}
\hline Duration (yrs) & No of patients & Percentage \\
\hline $\mathbf{1} \mathbf{~ y r}$ & 16 & 53.33 \\
\hline $\mathbf{1 . 1 - 2}$ yrs & 5 & 16.67 \\
$\mathbf{2 . 1 - 3}$ yrs & 5 & 16.67 \\
\hline $\mathbf{3 . 1}-\mathbf{4}$ yrs & 3 & 10 \\
\hline $\mathbf{4 . 1 - 5}$ yrs & 1 & 3 \\
\hline Total & 30 & 100 \\
\hline Mean \pm SD & $1.58 \pm 1.40 \mathrm{yrs}(0.08-4.50 \mathrm{yrs})$ \\
\hline
\end{tabular}

Table No. 5: Distribution of patients according to type of diet

\begin{tabular}{|l|c|c|}
\hline \multicolumn{1}{|c|}{ Type of diet } & $\begin{array}{c}\text { No of } \\
\text { patients }\end{array}$ & Percentage \\
\hline Oily/Spicy Food & 19 & 63.33 \\
\hline Normal & 7 & 23.33 \\
\hline Fast Food & 4 & 13.33 \\
\hline Total & 30 & 100 \\
\hline
\end{tabular}

Table No.6: Distribution of patients according to Nidra

\begin{tabular}{|l|c|c|}
\hline \multicolumn{1}{|c|}{ Sleep } & No of patients & Percentage \\
\hline $\begin{array}{l}\text { Asamyak } \\
\text { (Inadequate) }\end{array}$ & 17 & 56.67 \\
\hline $\begin{array}{l}\text { Samyak } \\
\text { (Adequate) }\end{array}$ & 13 & 43.33 \\
\hline Total & 30 & 100 \\
\hline
\end{tabular}

Table No. 7: Distribution of patients according to Malapravrutti

\begin{tabular}{|c|c|c|}
\hline Malapravrutti & No of patients & Percentage \\
$\begin{array}{c}\text { Aniyamit } \\
\text { (irregular) }\end{array}$ & 21 & 70 \\
$\begin{array}{c}\text { Niyamit } \\
\text { (regular) }\end{array}$ & 9 & 30 \\
Total & 30 & 100 \\
\hline
\end{tabular}

Table No. 8 : Distribution of patients according to Sharirik Prakruti

\begin{tabular}{|c|r|r|}
$\begin{array}{c}\text { Sharirik } \\
\text { Prakruti }\end{array}$ & \multicolumn{1}{|c|}{$\begin{array}{c}\text { No of } \\
\text { patients }\end{array}$} & \multicolumn{1}{c|}{ Percentage } \\
\hline Kapha Pittaj & 18 & 60 \\
\hline Vata Pittaj & 8 & 26.67 \\
\hline Vata Kaphaj & 4 & 13.33 \\
\hline Total & 30 & 100 \\
\hline
\end{tabular}

Table No. 9 : Distribution of patients according to Predominance of Manas Prakruti

\begin{tabular}{c|c|c|}
$\begin{array}{c}\text { Manas Prakruti } \\
\text { (predominance of } \\
\text { triguna) }\end{array}$ & $\begin{array}{c}\text { No of } \\
\text { patients }\end{array}$ & Percentage \\
\hline Tama & 16 & 53.33 \\
\hline Raja & 13 & 43.33 \\
\hline Satva & 1 & 3.33 \\
\hline Total & 30 & 100 \\
\hline
\end{tabular}

Table no. 10: Comparison of patient's Global Acne gradation on 0 day on 15th day

\begin{tabular}{|c|c|c|c|}
\hline Grading & 0 day & 15th day & $\chi 2$-value \\
\hline No Scar & $0(0 \%)$ & $9(30 \%)$ & \multirow{7}{*}{$\begin{array}{c}22.42 \\
\mathrm{p}=0.0001, \\
\mathrm{~S}\end{array}$} \\
\hline Mild(1-18) & $\begin{array}{c}17 \\
(56.67 \%)\end{array}$ & $21(70 \%)$ & \\
\hline $\begin{array}{c}\text { Moderate(19- } \\
\text { 30) }\end{array}$ & $8(26.67 \%)$ & $0(0 \%)$ & \\
\hline Severe(31-38) & $5(16.67 \%)$ & $0(0 \%)$ & \\
\hline $\begin{array}{c}\text { Very } \\
\text { Severe }(\geq 39)\end{array}$ & $0(0 \%)$ & $0(0 \%)$ & \\
\hline Total & $30(100 \%)$ & $30(100 \%)$ & \\
\hline Mean \pm SD & $19.36 \pm 8.55$ & $\begin{array}{c}5.60 \pm 4.9 \\
2\end{array}$ & \\
\hline
\end{tabular}

Statistical analysis was done by using descriptive and inferential statistics using chi - square test and software used in the analysis was SPSS 24.0 version and $\mathrm{p}<0.05$ is considered as level of significance.

\section{Discussion}

Total 30 patients were treated with Varuna Qwath for Mukha Prakshalan and Jatiphaladi Choorna for lepa. 
In distribution of patients according to age, maximum numbers of patients were found in age group of 21-25 years.

In course of puberty, there is transient rise in insulin and IGF-1 which inhibit FoxO1 regulation and allow the activated androgen receptor to elicit a chain of metabolic events. it leads to an excess production of keratinocytes and sebum.(18) Within the pilosebaceous unit. (19), (20)

In this study, it is predominantly found in females. It is supported by the study conducted by Raghubala et al. in which $62.5 \%$ patients were female. (21) It is assumed that decreasing in estrogens level may give rise to a relative increase in androgen level, and this imbalance may result in acne.

Cheeks are predominantly involved. The study conducted by $\mathrm{K}$ Raut and Raghubala et al, were also found involvement of cheeks. (22), (23)

Most of the patients were found to be consuming oily/ spicy food. According to Ayurveda, These dietary factors leads to disequilibrium of Agni causing vitiation of kapha and pitta.

According to modern medicine, Sebaceous glands may use fatty acids from the bloodstream for the synthesis of sebum. The Omega- 6 fatty acids are thought to induce more pro-inflammatory mediators and have been associated with the development of inflammatory acne. (24),(25)

Aniyamit malapravrutti is found to be predominant. According to Ayurveda, aniyamit malapravrutti may produce ama which is responsible for vitiation of kapha.

In the distribution of Prakriti, most of the patients were found to be having kapha Pittaj prakriti. Kapha and pitta Dosha have a major role in the samprapti of Mukhadushika

In the assessment of manas prakruti, $53.33 \%$ of patients had Tamsik prakruti, $43.33 \%$ of patients had Rajsik prakruti, 3.33\% of patients had Satvik prakruti.

As per the gradation of global acne scale, before treatment $56.67 \%, 26.67 \%, 16.67 \%$ patients were in mild, moderate and severe grade respectively. And after treatment no patient was in moderate and severe grade. 21 patients were in mild gradation and 9 patients had complete relief

\section{Mode of action of drug}

Varun (Crateva religiosa Buch-Ham) qwath was used for mukha Prakshalan (face wash). It may act due to its properties of Tikta, Kashaya Rasa, Laghu, Ruksha Guna and Ushna Virya and also having kapha pittahar and raktaDoshahar (26) effect. Tikta and Kashaya Rasa are helpful in alleviation of inflammation and ushna virya helps opening the pores.

As per phytochemical constituent Varun twak contains lupeol, butanol, triterpenoid etc (27) butanol also contains compound like succinic acid, lactic acid (28). Lactic acid has exfoliating property, Succinic acid also having antimicrobial. (29)
The lepa contains Jatiphala (Myristica fragrans Houtt), Raktachandan (Pterocarpus santalinus) and Marich (Piper longum Linn)

Jatiphal is having Katu tikta and kashaya rasa, tikshna, laghu guna, ushna virya and katu vipak. It has also shothhar(30) property. Myristicin is antiinflammatory property. Its aqueous and organic extract showed anti-microbial and anti-oxidant property. (31)

Marich is having katu rasa, katu vipak and ushna veerya and laghu and tikshna guna which pacify the kapha Dosha. It has ushna veerya however Rakta chandan is used to counteract and alleviate the ushna veerya of Marich avoiding its excessive local burning sensation. Chemical constituent of Marich contains Piperine. It is an antioxidant (32) as well as bioavailability enhancer that allows substance to remain in cells for a longer period of time. It also inhibits the production of pro inflammatory mediators i.e. IL6 and PGE2.

Raktachandan has katu, tikta rasa, katu vipak, sheeta veerya and laghu ruksha guna. Due to its guna, it acts as kapha pittaghna. It is indicated in raktagata $\operatorname{vicar}(33)$.

As per the study conducted by Bulle $\mathrm{S}$ et al, Pterocarpus santalinus contains flavonoids, essential oil, tannins, phenolic acids and polyphenolic compounds. It has Diaphoretic property and is useful to cure bilious infections and skin disease. It has antimicrobial, antiinflammatory and antioxidant effect (34).

\section{Limitation}

This study can be considered as pilot study because of its small sample size and less duration. and patients were not selected as per the specific type of acne

\section{Recommendations}

This study can be carried out on more number of patients by using this treatment protocol for long duration to approve its effect.Further study can be conducted by preparing 'ready to use' Varun Qwath and cream based Jatiphali yoga with the addition of oral bowel cleaner herb because aniyamit malapravrutti was found in significant number of patients.

This study can be continued by grouping the patient according to the type of acne

\section{Conclusion}

On the basis of observations of this study, it can be concluded that Young age group females were mostly affected. Mukhadushika was found predominantly in Kapha pittaj prakriti. The treatment protocol of Mukhadushika i.e Varun Qwath Mukhaprakshalan and Jatiphaladi yoga was helpful to alleviate inflammation. On application of Jatiphali yoga, mild burning sensation was observed for a very short time. In overall, this treatment protocol was effective as an anti-inflammatory and improves the blackish discoloration over skin. 
So, there was overall improvement in patient with this short duration treatment protocol.

\section{References}

1. Durai PT, et al. Acne vulgaris and quality of life among young adults in south india, IJD, volume 60 , issue 1,$2015 ; 60: 33-40$

2. Rea JN. et al. A community study of prevalence and use of medical care. BJPSM, June 1976;30(2):107114

3. Wolkenstein $P$, et al. French people and skin diseases: results of a survey using a representative sample. Arch Dermatol. 2003;139(12):1614-1619.

4. Johnson MT, et al. Skin conditions and related need for medical care among persons 1-74 years 1971-1974. Vital Health Stat. 1978;11:i-v,1-72

5. Knutsen-Larson $\mathrm{S}$, et al. Acne vulgaris: Pathogenesis treatment and needs assessment. Dermatol Clin, 2012;30:99-106

6. API textbook of medicine, Edited by G. S. Sainanai fifth edition, reprint 1994, published by association of physicians of India Bombay, Pg no.1266

7. Cordain L, et al. Acne vulgaris: a disease of Western civilization. Arch Dermatol, 2002,135: $1584-1590$

8. Textbook of dermatology Editor - R. H. Champion, J. L. Burton, F. J. G. Ebling Pg.no.1717

9. Shashtri A, Sushruta Samhita "Ayurved Tatva Sandipika" commentary , by Chaukhambha Sanskrit Publication, Varanasi -221001 (India) , reprint 2005, Nidansthan 13/3 \& 38 Pg. no. 282

10. Ambhore KP, Misar Wajpeyi SD. Comparative study of Lodhradi Lepa with and without Arogyavardhini Vati in the management of Yuvanpidika. J Indian Sys Medicine 2020;8:21-8.

11. Dwivedi L, Sushruta samhita, vol 2, Nidan sthan, chapter no 13, verse no 38Chaukhamba Sanskrit series, Varanasi 2002, p. 323

12. Shingel GD, editor, Susruta Samhita of Susruta acharya, English translation.Part 1. 2nd edi. Delhi. Chowkhamba Sanskrit Pratishthan.2007. p. 596

13. Murthy S, Madhava Nidana of Madhavakara. English translation. Varanasi. Chaukambha Orientalia. 2013. p - 181

14. Tripathi B. Astanga Hrdayam , Sutrasthana, Chaukhamba Sanskrit Pratishthan, Delhi, Reprint edition, 2009;1(25):19

15. Mallon E, et al. The quality of life in acne: a comparison with general medical condition using generic questionnaires. $\mathrm{Br} \mathrm{J}$ dermatol.1999; 140(4):672-6.[pub Med]

16. Tripathi E. Vaidyaratnam, kshudrayoga adhyaya, verse 82, 83Chaukhamba Sanskrut sansthan, Varansi , 2002, page no 154

17. Doshi A, et al. A comparison of current acne Grading systems and proposal of a novel system. IJD, 1997;36:416-8.
18. Caprio S. et al. Increased insulin secretion in puberty: a compensatory response to reductions in insulin sensitivity. J Pediatr. 1989;114(6):963-967.

19. Melnik BC. The role of transcription factor FoxO1 in the pathogenesis of acne vulgaris and the mode of isotretinoin action. G Ital Dermatol Venereol. 2010;145(5):559-571.

20. Melnik BC. Is nuclear deficiency of FoxO1 due to increased growth factor/PI3K/Akt-signalling in acne vulgaris reversed by isotretinoin treatment, 2010;162:1398-1400.

21. Raghubala et al. A comparative study of 'raktashodhak ghana vati' and 'mukhkantikara lepa' with vaman karma in the management of yuvanpidika acne vulgaris. wjpmr, 2017,3(10), 209-215

22. Raut K, a comparative study of vamana karma and shamana chikitsa in the management of yuvan pidika w.s.r. to acne vulgaris IAMJ.2017 oct

23. Raghubala et al. A comparative study of 'raktashodhak ghana vati' and 'mukhkantikara lepa' with vaman karma in the management of yuvanpidika acne vulgaris wjpmr, 2017,3(10), 209-215

24. Zouboulis CC. Is acne vulgaris a genuine inflammatory disease? Dermatology 2001; 203:277-9

25. Trebble $T$. et al. Inhibition of tumour necrosis factor-alpha and interleukin 6 production by mononuclear cells following dietary fish-oil supplementation in healthy men and response to antioxidant co-supplementation. 2003; 90:405-12

26. Sharma P, Dhanavatri Nighantu, Choukhamba Orientalia, Varanasi, reprint edition 2008,p-168

27. Sharma M, Reviews on Indian Medicinal Plants, Volume 8, Aravali publishers, 2009,p-21

28. Chanda S, Parakh P, "Phytochemical studies on stem bark of Crataeva nurvala Ham.”,JPR, 2011,4: 401-402

29. Theunisse L et al, Succinic acid: a promising multifunctional ingredient for cosmetic and personal-care applications, FNA,2018

30. Olaleye MT et al. Antioxidant properties of Myristica fragnance(Houtt) and its effect on selected organs of albino rats, AJB, 2013 July 5 (15)

31. Ojha Z, Dhanavatri Nighantu, Varanasi:Choukhamba Surbharati prakashan, reprint edition 2004,p-130

32. Vijayan KK, et al. Pharmacology, toxicology and clinical applications of black pepper, Hardwood Academic Publishers, 2000

33. Ojha Z, Dhanavatri Nighantu, Varanasi:Choukhamba Surbharati prakashan, reprint edition 2004,p-

34. Bulle S et al. Therapeutic Potential of pterocarpus santalinus L : An update Jan - Jun 2016, 10(19),43. 